Article

\title{
Rethinking Women's Empowerment: Insights from the Russian Arctic
}

\author{
Marya S. Rozanova ${ }^{1, *}$ and Valeriy L. Mikheev ${ }^{2}$ \\ 1 Department of Geography, The George Washington University, Washington, DC 20052, USA \\ 2 Rectorate, Russian State Hydrometeorological University, 192007 St. Petersburg, Russia; \\ V.Mikheev-rshu@yandex.ru \\ * Correspondence: marya_rozanova@gwu.edu
}

Received: 3 January 2020; Accepted: 5 February 2020; Published: 8 February 2020

\begin{abstract}
This article examines women's political empowerment in the Russian Arctic as an example of progress towards gender equality. In contrast to women's severe underrepresentation in Russian federal politics, a strong trend towards women's political empowerment can be observed in the Arctic regions of the country. Using the Nenets Autonomous Region as a case study, this article is aimed at narrowing the research gaps in women's leadership by examining the representation of female deputies in both the regional and local levels of government/self-government. Research on women's numerical representation indicates that women's participation and political empowerment in decision-making processes are manifested most vividly in predominantly indigenous communities. Placing a special focus on these Arctic communities, this study describes the historical and institutional roots that impact shifts in traditional gender role and contribute to a phenomenon of indigenous women's empowerment. Along with this positive pattern of women's leadership, this study also reveals an alarming trend of "reverse gender disparity" concerning men's severe underrepresentation in positions of power in indigenous communities of the North. The study results suggest that to achieve gender equality, a holistic approach to women's empowerment requires taking into account socio-cultural and historical contexts, as well as regional and territorial disparities.
\end{abstract}

Keywords: women's empowerment; gender; Arctic; indigenous peoples; Russia

\section{Introduction}

Enabling women to effectively participate in modern society is one of the most important advances towards global sustainable development, encompassing equal representation in the labor market, educational institutions, and political office (UN General Assembly 2015). Recent studies on gender equality (Sustainable Development Goal 5, or SDG5) demonstrate that despite an increasing global trend towards women's empowerment, levels of female participation vary dramatically across countries as well as across spheres of engagement (Global Gender Gap Report 2018; UN Women 2016; Sachs et al. 2019; Alexander et al. 2018). According to the Global Gender Gap Report 2018, the average gender disparity gap in the political sphere is $77.1 \%$ worldwide. By contrast, "Economic Participation" and "Educational Attainment" gaps average $41.9 \%$ and $4.4 \%$, respectively, and both indices indicate a continued downward trend (Global Gender Gap Report 2018, p. vii).

Russia, according to the "Political Empowerment" index has the largest gender disparity gap in politics and public administration of all the Arctic states. Limited by analyzing female participation in Russian federal legislative institutions and female appointments in top federal ministerial positions only, this index does not indicate a trend towards larger female leadership and further incorporation into regional political affairs and local self-government institutions in the Arctic-a territory that is traditionally viewed as a "male domain". To narrow this knowledge gap on women's political 
leadership in the Russian Arctic, this study presents the case of the Nenets Autonomous Region (Nenets Autonomous Okrug, hereinafter NAO), which ranks "medium" in women's participation in regional and municipal elective bodies and "very/extremely high" in having indigenous women (we define indigenous women in the NAO as women who identify themselves with Nenets or Komi indigenous peoples) in leadership positions in self-government institutions in the NAO rural, predominantly indigenous municipalities.

Drawing on Bennett (2002) and Narayan (2002), in this study we define indigenous female political empowerment at the local level as the enhancement of capabilities and achievements of indigenous women to engage and influence the local self-government institutions that serve the needs of their communities. This significant trend of indigenous female political empowerment in the Russian Arctic region in general, and in the NAO in particular, is an understudied topic. The present study seeks to narrow this research gap by highlighting grassroots public leadership by indigenous women, manifested most vividly in the system of self-government institutions-local elective bodies called municipal councils (munitsipal'nye sobraniia). Although a comprehensive elucidation of this phenomenon requires more research (Sundström and Wängnerud 2018), this study proposes three underlying causes for the prominent role of women in NAO self-government: (1) the Soviet doctrine of gender equality that was implemented in the Arctic as a form of women's liberation (partly through de-patriarchization of traditional family institutions); (2) the Soviet system of compulsory education for all children; and (3) women's personal goal-setting and career strategizing.

This study also reveals an alarming new trend of a "reverse gender disparity" and lowering levels of male social capital-both within Russian Arctic indigenous regions, such as the NAO, as well as in other circumpolar areas - that needs to be addressed in order to achieve SDG5.

In this paper, the NAO region represents a case study of how an overemphasis on incorporating gender issues into education systems and government policies can be counterproductive in achieving SDG5 in the long term. In the NAO instance, it was the emphasis on indigenous female empowerment and moderate male "traditionalism" that ultimately undermined efforts to achieve true gender equality.

\section{Literature Review and Methods}

\subsection{Literature Review}

While female activism has been studied extensively, the challenges of women's political empowerment in the Arctic and of emerging indigenous female leadership are a relatively new area of research (Larsen and Fondahl 2014; Oddsdóttir et al. 2015; Vinokurova et al. 2004). Accompanying processes of changing gender roles in indigenous communities have received more attention in Arctic social science literature in light of ongoing decolonization in the Arctic regions (with a special focus on feminist approaches, Vladimirova and Habeck 2018). These processes are well studied in Alaska (Bodenhorn 1990; Fogel-Chance 1993; Hamilton and Seyfrit 1994; Carson et al. 2011; etc.), Canada (Janovicek 2003; Rasmussen 2007; Hamilton 2010; Taylor 2011; Norris et al. 2013; Irlbacher-Fox 2015; etc.), and Greenland (Hamilton et al. 1996; Dahl 2010; Hamilton and Rasmussen 2010; etc.).

Most studies on gender-related issues in the Russian Arctic are conducted at the junction of ethnology and social anthropology on gender role transformation, or "gender shift" (Povoroznyuk et al. 2010). Among them are the following: a case study on the Nenets women in Yamal and the role of education and interethnic marriages in the context of the transformation of traditional gender roles (Nabok and Serpivo 2017); field research on Nenets women's changing social roles in the Yamal-Nenets Autonomous Region (Lyarskaya 2010); a case study of female nomads in Yakutia (Vinokurova 2017); a study on female migration strategies of Even and Koryak indigenous peoples in Magadan Oblast and the importance of educational and familial institutions as a mean of social mobility and urban integration (Khakhovskaya 2016); and a case study on the "female flight" of Nenets women in Yamal (Lyarskaya 2010). 
The indigenous female political leadership in the Russian Arctic has just recently gained attention as a topic of scholarly research (for instance, Ssorin-Chaikov 2003; Kulmala 2010; Kulmala 2014) and international policy (Jensen 2019). Work in this field is predominantly focused on the Soviet history of political socialization of indigenous women, including studies on women's incorporation into Soviet political institutions in the northeast of the USSR (Chukotka, Kamchatka, Yakutia, and Magadan regions), mechanisms for fostering indigenous feminism as part of Soviet state-building in the 1920-1930s (Slezkine 1994), and the ongoing transformation of indigenous women's political and socio-economic status (Dorzheyeva 2013).

In the NAO, indigenous women's ways of life have been addressed by Tuula Tuisku (study on changing indigenous female roles and historical prerequisites for female flight from Nenets tundra, Tuisku 2001), Vladislava Vladimirova (case study on Nenets women's strategies and personal struggles between tradition and modernity, Vladimirova 2018), Yury Sumarokov (research on deviant and suicidal behavior in Nenets indigenous communities and the role of gender, Sumarokov et al. 2014), and the co-author's study on underlying causes of the urbanization of Nenets indigenous women in the NAO (Rozanova 2019).

\subsection{Data Sources and Methods}

Data for the NAO population distribution by ethnicity, area of residence, and general socio-demographic and economic characteristics (sex, occupation sphere ("traditional" vs. "non-traditional"), education level), were obtained from the Russian Censuses of 2002 and 2010 (no other official demographic data on the NAO population are available between or after these two censuses) and the NAO municipal councils' websites, as well as data received from the focal municipal councils.

In order to measure female political participation at the regional, municipal, and local levels, data for qualitative variables were collected from the NAO legislative body (Sobranie deputatov) website, City Council of Naryan-Mar website, and municipal councils' websites that provide information about 2016-2018 elections to the municipal councils. This study gave special attention to municipal councils as local-level institutions of self-governance. The qualitative variables in this study include the following ratios: (1) females with seats in the municipal councils over the male value; (2) female heads of the municipal councils over the male value; and (3) the educational attainment of female elected deputies over the male value.

The conceptual basis of this study is built upon the authors' in-depth interviews with leaders of the indigenous communities (representatives of the Russian Association of Indigenous Peoples of the North (RAIPON) and the Nenets Indigenous Association "Yasavey"); interviews with high-ranking NAO administration officials and representatives of the Committee on Indigenous Affairs and Ethnic Policy; and specialists in the schools' administration in the NAO.

This study also includes the results of an informal survey conducted with Dr. Andrey Gretsov in Pyrerka boarding school in Naryan-Mar in 2017-2018. This questionnaire on career goals and life strategies was completed by 50 respondents, predominantly indigenous students (14-17 years old), most of whom originated from families pursuing traditional lifestyles in remote rural areas of the NAO.

\section{Findings}

\subsection{Gender Disparities in Modern Russia's Politics: The Higher the Stakes, the Deeper the Gap}

\section{"No Room for Women in Big Politics"}

In modern Russia, women are highly underrepresented in both legislative and executive governmental bodies, especially at the federal level where the political stakes are high. According to the Global Gender Gap Report 2018, Russia's federal government institutions were so male-dominated that the country earned a rank of 123 out of 149 countries evaluated for female empowerment, placing 
Russia between Egypt (ranked 122) and Sierra Leone (ranked 124) (Global Gender Gap Report 2018, p. vii). In 2018, the female-to-male ratios of the upper and lower houses of Russia's national legislature, the Federal Assembly (Federal'noe Sobranie), were $15.8 \%$ and $84.2 \%$, respectively.

Women's underrepresentation has a long history in Russia. Although the patriarchal order of Tsarist Russia was officially overturned in 1917, institutionalized inequality persisted throughout the Soviet Era and into the modern day. In spite of the heavily promoted Soviet concept of gender equality accompanied by global trends towards women's participation in public spheres, Russia failed to enact comprehensive mechanisms towards true equality, resulting in limited achievements towards SDG5, especially in the political sphere (Lapidus 1978; Heitlinger 1979; Engel and Posadskaya-Vanderbeck 1998; Kochkina 2003; Blomberg et al. 2017; Racioppi and O'Sullivan See 2009).

As with many countries going through post-socialist transformations (Einhorn 2006; Saarinen et al. 2014; Ayvazova 2014, 2017), Russia's political culture is based largely on traditional values. This traditionalistic approach shapes the official discourse on gender differences, influencing both the representation and status of women in national elective bodies (Inglehart and Norris 2003; Norris 2004; Chandler 2013). This trend back towards traditionalism is also supported by post-Soviet women themselves, as in their everyday lives during the Soviet Era, they often experienced "the gap between Soviet egalitarian discourse and the reality of women's 'double' employment (work outside of the home in addition to bearing the main responsibility for home and children) and the limited participation $<\ldots>$ in political decision-making" (Blomberg et al. 2017, p. 13).

Since the mid-2000s, the idea of gender equality has often been misinterpreted as solely the promotion of values such as "radical feminism", child-free movements, LGBTQ freedoms, and sexual liberation. Following this interpretation, it is portrayed in the official discourse as foreign and incompatible with traditional all-Russian (Russians as rossiyane) cultural values such as the "traditional family" that is viewed through "'traditional gender roles' that allotted to women the function of caregiver and to men the role of breadwinner" (Blomberg et al. 2017, p. 43).

This trend has been aggravated by recent tensions with Western countries and the growing presence of religion (The Russian Orthodox Church 2006) in public and political life. Part of the politicization of the discourse on women's empowerment has involved presenting a concept of gender equality as a fundamental barrier to a sustainable demographic situation requiring higher birth rates (Upadhyay et al. 2014) and even as a threat to the national development goals of the Russian Federation.

The social construction of women's roles as "caregivers" and men as "breadwinners" has contributed to a gender gap — not only quantitative, but also qualitative-in power distribution in public governance. As a consequence, those few deputy women are generally expected to participate in the legislative decision-making process only in spheres tied to the feminine "caregiver" role where the stakes are relatively trifling. Among those traditional gender-specific spheres are family politics, culture, childcare, primary and secondary school education, social work, and medicine (to a lesser extent). Women are almost completely excluded from spheres where the stakes are high, such as energy, economic policy, and security and defense, as these are considered to be the male domain. The gendered make up of working committees in both houses of Russia's Federal Assembly clearly demonstrates such inequalities (Tables 1 and 2). 
Table 1. Female elected deputies' membership in selected committees of the House of Representatives. The 2016 election. (The State Duma Official Website 2019 (Gosudarstvennaia Duma)).

\begin{tabular}{cccc}
\hline Committees & Total Number & $\begin{array}{c}\text { Number of Female } \\
\text { Elected Deputies }\end{array}$ & $\begin{array}{c}\text { Female Elected } \\
\text { Deputies, Percent }(\downarrow)\end{array}$ \\
\hline Issues of Family, Women, and Children & 9 & 8 & 89 \\
\hline Culture & 11 & 6 & 55 \\
\hline Education and Science & 18 & 7 & 39 \\
\hline Health Protection & 21 & 5 & 24 \\
\hline Defense & 12 & 1 & 5 \\
\hline Natural Resources, Property, and Land & 20 & 1 & 4 \\
\hline Energy & 28 & 1 & 3 \\
\hline $\begin{array}{c}\text { Economic Policy, Industry, Innovation, } \\
\text { and Entrepreneurship }\end{array}$ & 30 & 1 & 0 \\
\hline Financial Market & 12 & 0 & \\
\hline
\end{tabular}

Table 2. Female senators' membership in selected committees of the Senate (2019). (The Federation Council (Sovet Federatsii Official Website 2019)).

\begin{tabular}{cccc}
\hline Committees & Total Number & $\begin{array}{c}\text { Number of Female } \\
\text { Senators }\end{array}$ & $\begin{array}{c}\text { Female Senators, } \\
\text { Percent ( } \downarrow)\end{array}$ \\
\hline Science, Education, and Culture & 16 & 6 & 38 \\
\hline Social Policy & 13 & 5 & 38 \\
\hline Defense and Security & 15 & 2 & 13 \\
\hline $\begin{array}{c}\text { Federal Structure, Regional Policy, Local } \\
\text { Government, and Northern Affairs }\end{array}$ & 21 & 2 & 0 \\
\hline Economic Policy & 18 & 0 & 10 \\
\hline
\end{tabular}

The barriers that restrain women from substantive political empowerment are not legislative shortcomings (for instance, Decree of the Government of the Russian Federation 2018), but rather traditional values manifested as cultural constraints on women's leadership beyond issues concerning children and families (Ayvazova 2016). Thus, female political leaders face social stigma not only from male colleagues but also from an electorate that favors minimizing the participation of women in politics and public administration. A series of nationwide surveys conducted by the Levada-Center from 2006 to 2017 (Kochergina 2017) indicate that Russian citizens are increasingly (1) displeased about women's involvement in political activities (from $20 \%$ in 2006 to 30\% in 2017) and (2) against equal opportunities for men and women in obtaining top government positions (from $24 \%$ in 2006 to $38 \%$ in 2017). Moreover, Levada's surveys found declining public support for the idea of a female President of Russia in the mid-term future (10-15 years perspective) (from $45 \%$ in 2006 to $33 \%$ in 2017) (Kochergina 2017).

Despite the fact that such views often dominate the all-Russia public sphere, especially in federal politics, in many aspects, the Arctic NAO region represents a significant departure from this trend. Although there is a gender gap in the NAO's regional legislative body, it is less pronounced than in the Federal Assembly. At the city municipal level, women hold office in roughly equal proportion to men, and there is a trend in the NAO local self-government bodies, especially of indigenous municipalities, towards an overrepresentation of women in leadership positions. 


\subsection{Female Rising in the Arctic Region of NAO}

"If Not Us, Who?"

The NAO is a classic example or the "Arctic resource curse" in which regional development and economic prosperity mostly depend on the raw materials global market, thus limiting the capabilities of regional government institutions. The oil industry is central to the NAO's economy, with an overwhelming proportion of the region's budget coming from resource taxation: in 2015, 85\% of the NAO's budget revenue came from taxes levied on oil companies, and in 2016 and 2017, these taxes accounted for roughly $80 \%$ (Neftegaz.RU 2018). Because of the political sway of the oil industry combined with highly centralized federal power over Russia's Arctic regions, legislative and executive authorities in the NAO hold limited power in both decision-shaping and decision-making and are practically relegated to low-stakes decisions within their specific areas of competency, thus allowing women to participate more fully in the political sphere.

The results of the regional elections of 2018 to the NAO legislative body (Sobranie deputatov) demonstrate the strong trends towards gender equality in this Arctic region. In the 2018 elections, women made up 28\% of NAO's regional legislators (5 out of 18 seats) (Sobranie deputatov Official Website 2019). Importantly, female elected deputies in Sobranie deputatov are effectively equally represented in four out of five permanent committees, remaining underrepresented only on the Committee on Education, Culture, and Sports, dealing with issues that are traditionally viewed as a "female prerogative" (except the area of sports) (Table 3) (Sobranie deputatov Official Website 2019).

Table 3. Female elected deputies' membership in committees of the Nenets Autonomous Region (NAO) legislative body (Sobranie deputatov). The 2018 election (Sobranie deputatov Official Website 2019).

\begin{tabular}{cccc}
\hline Committees & Total Number & $\begin{array}{c}\text { Number of Female } \\
\text { Elected Deputies }\end{array}$ & $\begin{array}{c}\text { Female Elected } \\
\text { Deputies, Percent }(\downarrow)\end{array}$ \\
\hline Economic Policy and Budget & 8 & 4 & 50 \\
\hline $\begin{array}{c}\text { Nenets and Other Indigenous Peoples, } \\
\text { Ecology, and Natural Resources }\end{array}$ & 7 & 3 & 43 \\
\hline Government and Municipal Affairs & 7 & 3 & 43 \\
\hline Social Policy & 10 & 4 & 40 \\
\hline Education, Culture, and Sports & 8 & 2 & 25 \\
\hline
\end{tabular}

It is important to note that women's political leadership in the NAO is not yet profoundly institutionalized, as the results of previous elections to the Sobranie deputatov indicate the unsteady trend towards larger female leadership and further incorporation into regional political affairs. In the 22nd Election (1994-1996), women obtained 20\% (3 seats out of 15); 23rd Election (1996-2000)-19\% (3 seats out of 16); 24th Election (2001-2005) - 40\% (6 seats out of 15); (no information available for the 25th Election); 26th Election (2009-2014) - 18\% (2 seats out of 11); and 27th Election (2014-2018)-16\% (3 seats out of 19) (Sobranie deputatov Official Website 2019).

Nevertheless, the NAO's most exceptional case of women's representation is in the Senate (Sovet Federatsii) - the body that has historically highlighted the most vivid struggles women face in gaining admission to national political office. For instance, as of 2019, of the 170 senators elected and appointed, only 29 were women (Sovet Federatsii Official Website 2019). In 2018, both NAO representatives nominated to the Sovet Federatsii were women-Senator Olga Starostina (of indigenous Nenets origin) and Senator Rimma Galushina.

In the NAO, women also tend to be more equally represented at the municipal level. In two recent elections to the City Council of Naryan-Mar (the administrative center and the only city in the NAO with more than half of the region's population), women achieved a plurality or near-plurality 
of electoral victories, securing 6 seats out of 11 (55\%) in 2017 and 7 seats out of 15 (46.6\%) in 2019 (PIRE Indicators 2019).

At the local level (munitsipal'nye obrazovaniia), female representation in municipal councils (self-government elective bodies, Sovety deputatov) is, on average, even more pervasive, particularly in rural, predominantly indigenous communities. In the $\mathrm{NAO}$, indigenous peoples are well represented: according to the 2010 Census (The Russian Census of 2010 2010), around 7504 Nenets and 3623 Komi live on NAO territory, comprising $18 \%$ and $7 \%$ of the share of the NAO population, respectively. The leading ethnic group ("titular nation")—Nenets—live mainly in rural village-type settlements that are highly unevenly scattered over the vast territory.

Rural municipal districts where indigenous peoples-Nenets and Komi-make up more than $40 \%$ of the total population include the following: Kaninskiy ( $57 \% ; 11,339$ total population), Karskiy (majority, exact numbers are unavailable; 705 total population), Kolguev (97\%; 470 total population), Khoseda-Khardskiy ( $89 \%$; 687 total population), Khorey-Verskiy (40\%; 843 total population), Malozelmelskiy (67\%; 1009 total population), Primorsko-Kuyskiy (56\%; 1875 total population), Shoinsky (40\%; 352 total population), Timanskiy (68\%; 956 total population), and Yusharskiy (57\%; 748 total population) (municipal councils' official websites).

In these focal municipalities, the local elections of 2016-2018 brought into power a majority of women in eight out of 10 municipalities, forming a vast or an overwhelming majority in seven municipalities (Figure 1) and resulting in a significant shift in favor of female deputies. Overall, elected women hold 51 municipal seats (72.9\%) and men only 19 (27.1\%) (as of 1 January 2020).

These results demonstrate a special importance of "indigenousness" in the processes of female empowerment in the Arctic. For comparison, in other NAO communities, predominantly non-indigenous ones (Iskateley, Kotkinskiy, Velikovisochnoe, Tel'visochnyy, Kotkinskiy, Pustozerskiy, Omskiy, Amderma, Andeg, and Zapolyarnyy), the overall results of the local elections reveal that both women and men are almost equally elected: altogether, women hold 44 municipal seats $(53.7 \%)$ and men hold 38 seats (46.3\%) (as of 1 January 2020).

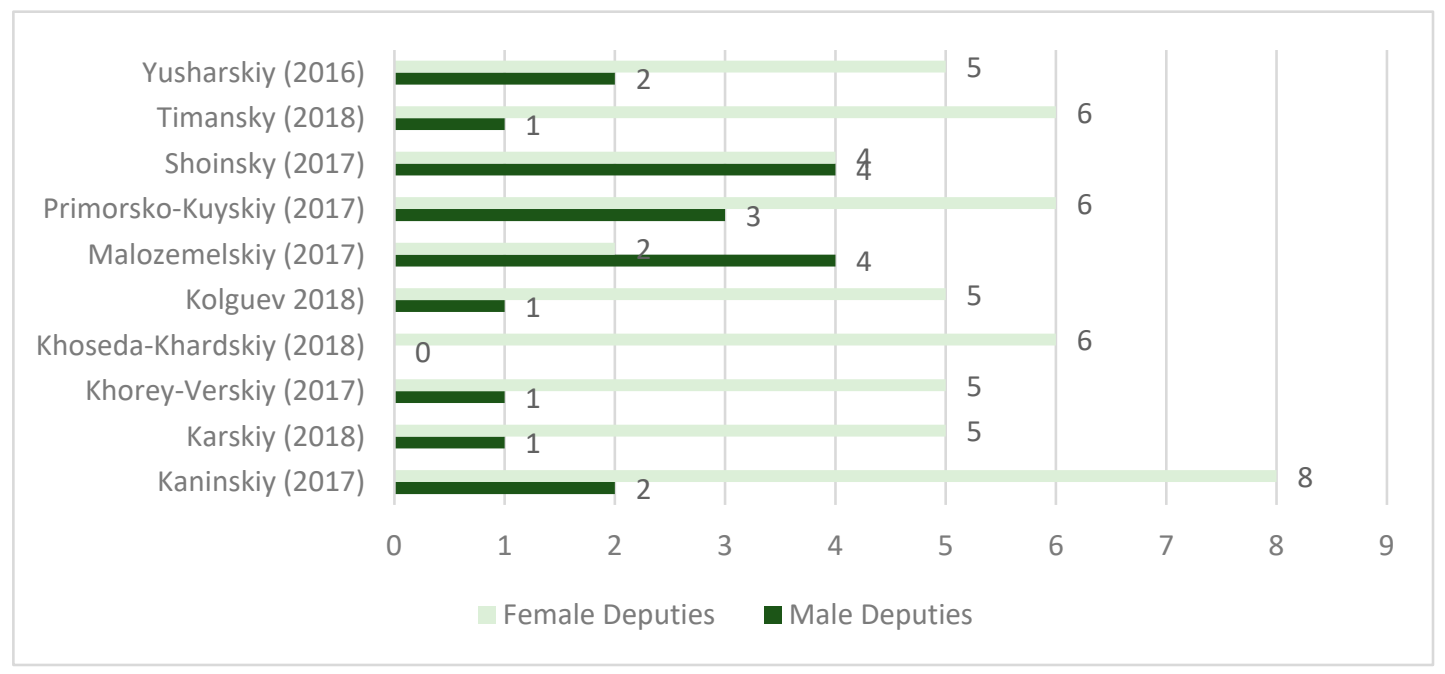

Figure 1. Gender disparity in focal Nenets municipal councils: elected female and male deputies, by numbers (elections of 2016-2018). (Authors' calculation based on the NAO municipal data, as of 1 January 2020).

Among the total number of elected female deputies in focal councils, indigenous women hold 36 seats $(70.6 \%)$ (Figure 2). Although underrepresented in three municipal councils (Malozemelsky, Shoinsky, and Yusharskiy), they demonstrate a strong leadership position in the local self-government institutions. Indigenous male deputies are almost equally presented with non-indigenous deputies 
and are holding 11 seats (57.9\%), underrepresented in only two municipal councils (Kaninsky and Karsky) (Figure 3). All in all, they are far behind their female indigenous counterparts.

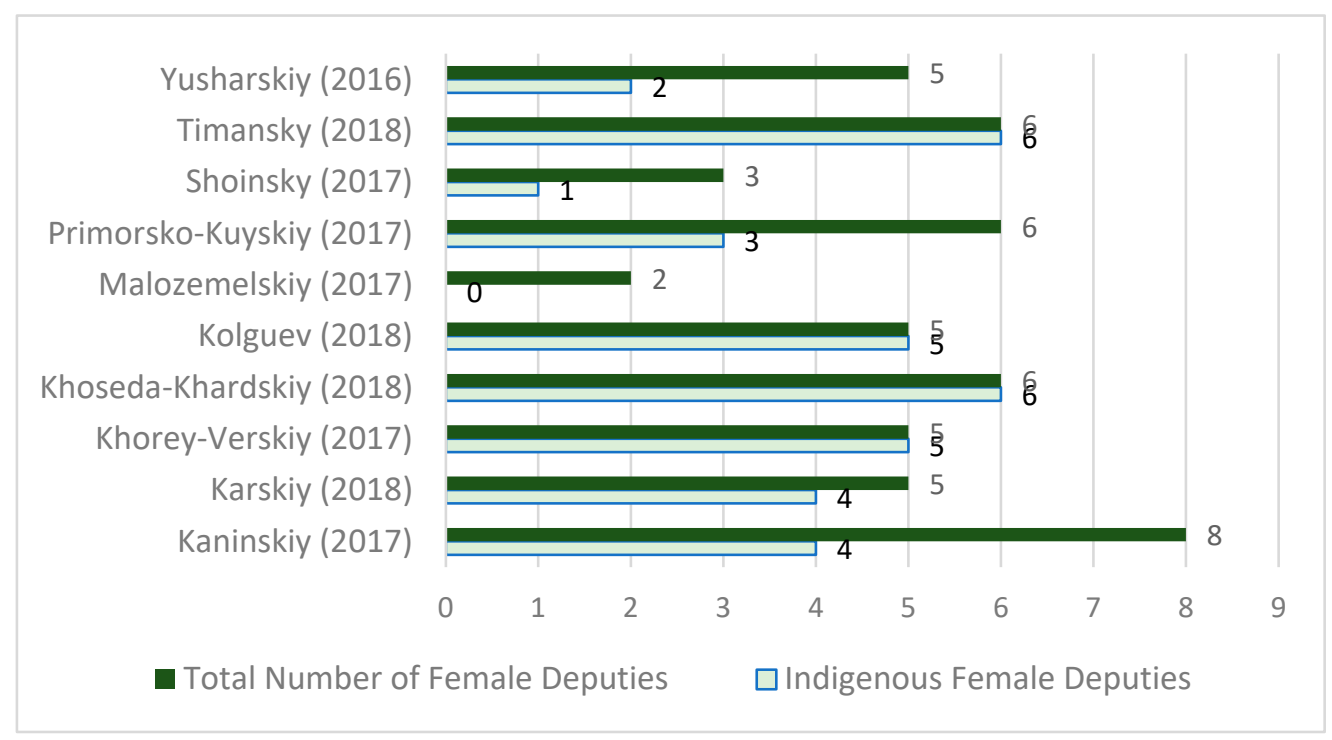

Figure 2. Female deputies in focal Nenets municipal councils: female deputies, total, and indigenous female deputies, by numbers (elections of 2016-2018). (Authors' calculation based on the NAO municipal data, as of 1 January 2020).

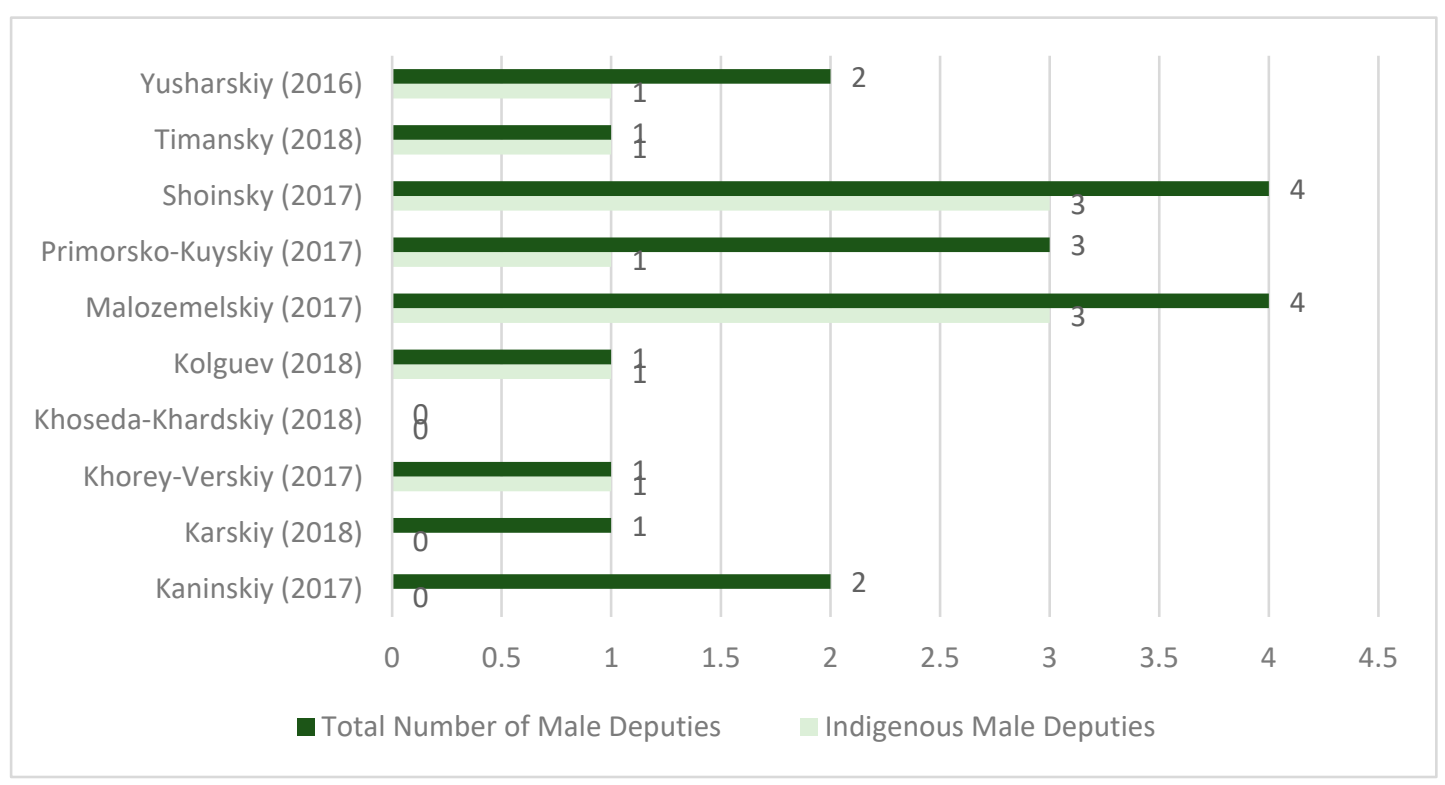

Figure 3. Male deputies in focal Nenets municipal councils: male deputies, total, and indigenous male deputies, by numbers (elections of 2016-2018). (Authors' calculation based on the NAO municipal data, as of 1 January 2020).

These most recent elections also revealed a dramatic disparity in education attainment among elected male and female municipal councils' deputies. In particular, the gap in achieving a higher education diploma ( $44 \%$ of female deputies and $25 \%$ of male deputies) clearly demonstrates that women elected to municipal councils tend to be much better educated than their male counterparts (Figure 4). 


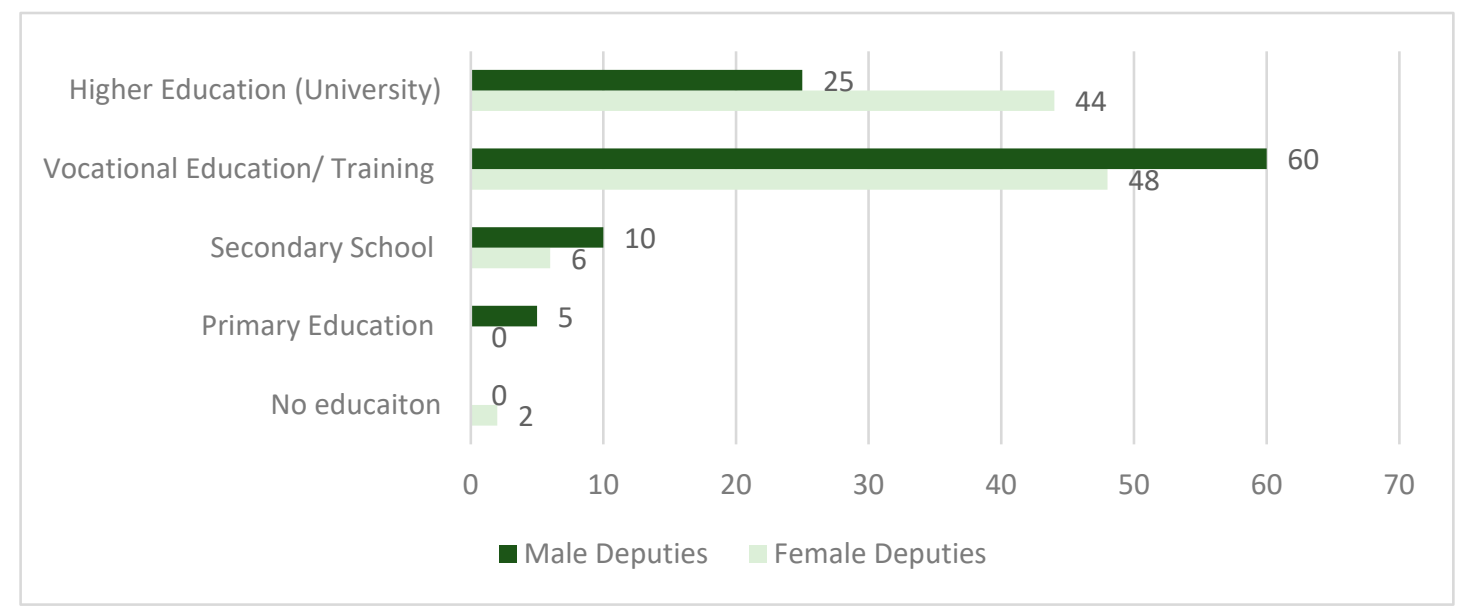

Figure 4. Education attainment disparity among male and female deputies in focal Nenets municipal councils (\%). (Authors' calculation based on the NAO municipal data, as of 1 January 2020).

A higher education diploma is particularly valuable for those aspiring to become heads of municipal councils. In all ten focal Arctic municipal districts, the heads have obtained university diplomas, with six of these districts (Kaninsky, Karsky, Khoseda-Khardsky, Khoreisky, Kolguev, and Shoinsky) being currently led by women.

There are three major factors that significantly contribute to the political trend towards women's empowerment in these focal Arctic settlements: (1) the Soviet doctrine of gender equality that was implemented in the Arctic as a form of women's liberation (partly through de-patriarchization of traditional family institutions); (2) the Soviet system of compulsory education for all children; and (3) women's personal goal-setting and career strategizing.

\subsection{Historical and Institutional Roots of Indigenous Women's Empowerment in the NAO}

\subsubsection{Top-Down Soviet De-Patriarchization}

The female political engagement process has a long history in the NAO, starting back in the 1930s when the indigenous peoples of the north first experienced wide-reaching social changes as a result of Soviet industrialization and ideologization of the Arctic. The new ideology viewed traditional social institutions as "archaic" and anti-Soviet, and the concept of equality and liberation of the Soviet woman (Dorzheyeva 2013) was implemented as a top-down approach to defeat the patriarchal regime and foundations of traditional family. This Soviet campaign had a profound and, in many cases, negative social impact on indigenous communities.

In accordance with indigenous Nenets traditions, women were excluded from participating in indigenous "community councils where issues related to the family as a whole were discussed" (Serpivo 2014, p. 443). These traditions also restricted women's physical presence in the "sacred" half of the home, banned women from taking "non-traditional" social and professional roles, and imposed many other gender-specific restrictions on religious and social aspects of life. All these traditional norms were interpreted by Soviet ideologists as degrading to the social status of women in Nenets communities (Lyarskaya 2010, pp. 11-12) and disenfranchising Soviet women in general (Serpivo 2014).

In order to unlock the full potential of women in the socio-economic spheres of a rapidly modernizing country and to dilute labor shortages, Soviet authorities established an institutional framework for greater women's participation in both the labor market and in societal/political decision-making processes. Early Soviet regimes supported and encouraged the emergence of indigenous feminism by recognizing political and socio-economic equality on the basis of gender and ethnicity (the 
first general principles were presented in the 1918 Constitution of the Russian Soviet Federative Socialist Republic (The 1918 Constitution of the Russian Soviet Federative Socialist Republic 1918).

In the NAO, the First Regional Conference of Nenets Women was held in 1937 in Naryan-Mar. Among the participants were 35 Nenets women from Malaya, Bol'shaya, Timan, and Kanin tundra-potential "active and conscious builders of communism". It was the beginning of a process that would divide Nenets women into two major groups-nomadic culture-bearers/tradition keepers and Soviet "liberated" women following a new style of living in urban-type sedentary settlements and contributing to economic development of the Soviet Union.

The aim of the Conference of Nenets Women was to foster a discussion of the Soviet Constitution of 1936 (The 1936 Constitution of the Soviet Union 1936) and its new legal norms. These progressive new ideas fell into the following categories: (1) social and economic issues, including guarantees of a seven-hour workday, paid annual leave, and free medical care; (2) educational guarantees of universal compulsory eight-year education, elimination of school fees for all types of education, a system of state scholarships, and cultural benefits such as schooling in native languages, and (3) recognition of women's rights and full gender equality (Article 122. Women in the U.S.S.R. <Union of Soviet Socialist Republics $>$ are accorded equal rights with men in all spheres of economic, state, cultural, social and political life.).

In addition to codifying equal rights on the basis of gender, the new Soviet doctrine officially recognized cultural equality and the prevention of any forms of nationalism or xenophobia. Legally, it opened prospects for indigenous women to participate in politics and public administration not only at the local or regional levels but also at the federal level (Article 123. Equality of rights of citizens of the U.S.S.R. <Union of Soviet Socialist Republics>, irrespective of their nationality or race, in all spheres of economic, state, cultural, social and political life, is an indefeasible law. Any direct or indirect restriction of the rights of, or, conversely, any establishment of direct or indirect privileges for, citizens on account of their race or nationality, as well as any advocacy of racial or national exclusiveness or hatred and contempt, is punishable by law.).

In practice, the implementation of these progressive norms, especially in the sphere of female political activism (Article 137. Women have the right to elect and be elected on equal terms with men), was not an easy task. In many cases, Soviet social norms were highly incompatible with the traditional values governing social and familial institutions based on patriarchal order. In addition, hierarchy of authority and relations based on kinship presented a clear threat to the communist regime. Soviet authorities launched successful campaigns to encourage indigenous female activism to help break down these traditionalist norms, thereby increasing the legitimacy of the new Soviet regime in the NAO (Tarmakhanov and Badmatsyrenova 2010).

Overall, indigenous women demonstrated a higher level of engagement: in the 1930s, many of them participated in educational programs, special medical vocational trainings, and even in theatrical arts (in the NAO, in the first Nenets troupe, all eleven members were indigenous Nenets women). Stepanida Apitsyna (1884-1956) served as a role model of the "liberated" Soviet woman. She was the first indigenous female leader and a head of the municipal council in the Malozemelskaya tundra. She was also the chairwoman of the First Nenets Reindeer Group (kolkhoz) and a delegate to the All-Russian Central Executive Committee in the 1934 Session (VTSIK, the highest legislative, administrative, and revising body of the Russian Soviet Federative Socialist Republic at that time). In 1938, she supported the Soviet project on transition of the indigenous nomadic way of life towards a semi-sedentary one for the Nenets. The accomplishments of Apitsyna, all of which were extraordinary for a woman of her time, clearly demonstrate how impactful the implementation of communist ideology was in the NAO.

Yet, many paid a high price: perceived as a minority group, these "sovietisized" indigenous women were often marginalized by their own families and communities as "strangers" and had no way back. 
As the NAO indigenous women underwent a process of ideological sovietization, they also experienced a gradual departing from traditional norms and institutions as a result of the following processes:

- Equalizing women's and men's legal and socio-economic statuses in the Soviet economy and statehood (Ayvazova 1998); limiting the concept of gender-specific jobs in favor of expanding of the list of unisex professions in the Soviet industrial complex.

- Transitioning from nomadism to a sedentary life accompanied by "social nomadism", which offered a wide range of new social statuses and roles to explore (Kiselev and Moldanova 2018, p. 575).

- Enrolling women in primary and secondary schools and universities, as well as vocational training programs (as a result, within a few decades, there was a radical turn from the almost absolute illiteracy of indigenous women in the Arctic towards the formation of a female indigenous intelligentsia).

- Changing mothers' roles in children's upbringing (traditional child-rearing was interpreted as a hindrance on the path towards woman's self-realization) by establishing a system of kindergartens and boarding schools starting in the 1930s.

- Encouraging indigenous female korenizastsiya (nativization) through participation in the formation of the regional and local government bodies, as well as in a growing economic (industrial) sector (Kiselev and Moldanova 2018, p. 575).

Over the past 80 years, communist ideology combined with intensive industrial exploration in the NAO led to radical changes in the lifestyle and living conditions of its indigenous residents as well as to the transformation of their political, social, and familial institutions. By historical standards of a largely unaltered Arctic civilization, these unprecedented rapid changes did not lead to the complete disappearance of the nomadic way of life or the subsistence economy, but they did severely affect the majority of Nenets people in the region and indigenous women in particular. Overall, women had greater opportunities to achieve social recognition outside the family, gain economic independence, further their education, and fuel personal and professional growth and social mobility. However, the Soviet top-down approach also forced them to give up many of their traditions, including a nomadic family life together with their communal rights to the land. This approach revealed and exacerbated a persisting unresolved ambivalence-Soviet authorities promoted female political empowerment by taking away their "fate control" (Larsen et al. 2015).

\subsubsection{Gender Disparities in Education Strategies and Career Orientation}

In the NAO, the communist ideology that aimed to eliminate all forms of gender inequality and to achieve female empowerment had been relatively effectively embedded in the system of compulsory primary and secondary education, when, in the late 1950s, a system of boarding schools was established for children from the tundra (Lyarskaya 2004). Although this system of education was designed to stimulate political and social assimilation, adaptation to an urban environment, and training for non-traditional professions (Lyarskaya 2006), it was also relatively successful in establishing a solid ground for gender equality in many sectors of the economy.

As part of their standard curricula, students were taught that the indigenous way of life in the Arctic tundra was too hard, uncivilized, and dangerous for women and children (harsh, cold climate; lack of amenities and facilities; daily, hard, physical work for women that included dismantling and assembling the tent (chum) at every move; loading deer or bark tires, poles, etc. on special sleighs (Khakhovskaya 2016, p. 66); lack of opportunities for personal growth and self-realization (Nabok and Serpivo 2017; Lyarskaya 2010)). As an alternative, the boarding schools provided female students with an opportunity to "acquire skills and competencies ... to improve their self-perception of their capabilities" (Segovia-Pérez et al. 2019) in order to obtain relevant qualifications for a competitive urban labor market. Therefore, over time, many of them managed to avoid so-called "indigenous path 
dependency" by choosing further education or vocational training and expressing increased ambitions to pursue careers in traditionally male-dominated spheres.

The gender shift in occupational aspirations was also revealed in an informal survey (conducted by Marya Rozanova and Andrey Gretsov in Pyrerka boarding school in Naryan-Mar in 2017-2018 with 50 respondents, who were predominantly indigenous students (14-17 years old), most of whom originated from families pursuing traditional lifestyles in remote rural areas of the NAO). The gathered qualitative data used for the ratio of career strategies (traditional vs. non-traditional) over the male value demonstrate significant shifts in female students' career strategizing. Although female respondents were still likely to focus on career-building in more traditional "female" domains (i.e., education, medicine, culture (including "ethno-cultural activism"), at the same time they demonstrated their ability to make strategic life choices and did not hesitate to set a goal of becoming prosecutors, ecologists, geologists, chemists, architects, policewomen, military personnel, lawyers, economists, movie producers, etc. It is noteworthy that among students' preferred professions, there were no professions related to the sphere of public politics and government (municipal) administration, which indicates a low level of political ambitions and aspirations among students at that stage of their lives.

Based on the students' choice of specific professions, it is possible to presume their further educational strategies. Female students expressed a strong interest in professions that require higher education and vocational training, whereas male students, in general, focused on professions that do not require special training (Figure 5).

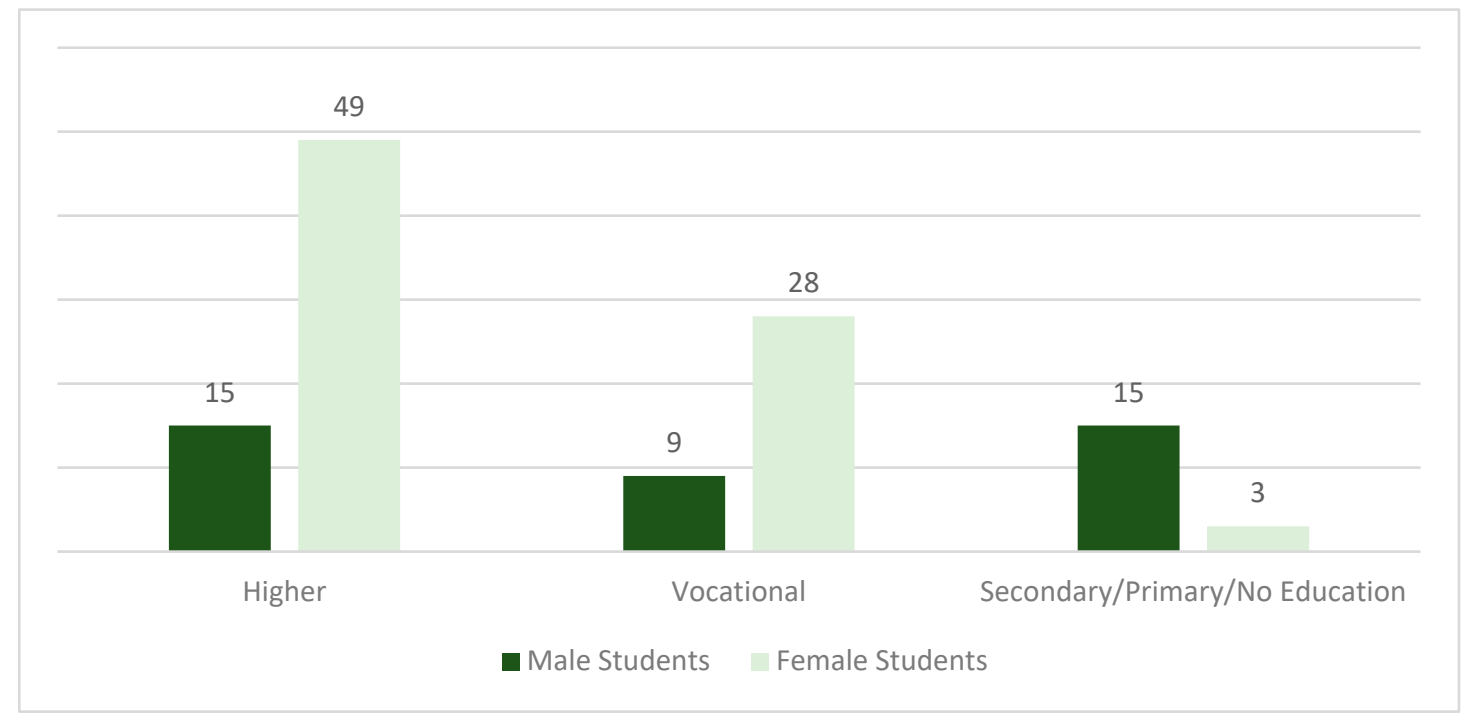

Figure 5. Required level of professional education based on student's choice of desirable professions (composed on the basis of summarizing the data of professions indicated by the respondents) (\%) (The informal survey was conducted by Marya Rozanova and Andrey Gretsov in Pyrerka boarding school, Naryan-Mar, 2017-2018).

This informal survey also revealed the signs of a trend common for many indigenous communities across the Arctic states: many young indigenous men, unlike women, "appear to have been socialized into a path dependency and consequently have difficulties accepting alternative paths and changes" (Rasmussen 2015, p. 38). They tend to narrow their choices (sometimes on their own, sometimes as a part of a family decision) in favor of "traditional male professions" (mechanics, snowmobile drivers, etc.) (Rozanova 2019, p. 66) that are complimentary to indigenous ideas of traditional "masculine" professions and help them with reindeer herding and hunting (Eikjok 2007; Ventsel 2018). According to the census (The Russian Census of 2002 2002), about $41.2 \%$ of the total population of Nenets, predominantly men, work in the traditional economy (reindeer husbandry, hunting, gathering, 
and fishing/fish farming) on a permanent basis. As of 2018, this traditional branch employed about 1000 people (predominantly Nenets men), mostly in reindeer husbandry.

Among the main reasons for the indigenous men's decision to remain in traditional Nenets professions are (1) protection against unemployment (a lack of good education aggravated by a lack of jobs in remote villages of this Arctic region pushes them to engage in reindeer husbandry (Perevalova 2015)); (2) possibility of preserving the ethnocultural identity of the Nenets as indigenous people of the north (reindeer husbandry remains "the only branch of the traditional economy capable of ensuring cultural reproduction" (Sokolovskiy 2008, p. 64)); and (3) governmental support for traditional economic occupations in the NAO (indigenous peoples pursuing the traditional way of life and obtaining traditional occupations are protected by state and eligible for getting social guarantees and monetary payments (The Law of the Nenets Autonomous District 2008)).

In indigenous communities, the sphere of local self-governance is not widely viewed as a "male" domain, because it lacks this traditionalist appeal ("masculinity"), leaving politics as a vacant niche for women.

By making these professional and life choices, men ultimately find themselves in a situation when they are "stuck, without options for mobility both geographically and socially" (Rasmussen 2015) and thus might experience further social marginalization (Heleniak 2019). By contrast, women, by obtaining higher social status through education and professional development, gradually come to constitute the indigenous social and political elite, both in their communities and beyond.

\section{Conclusions}

Although gender equality remains a distant dream in Russia, the magnitude of women's political empowerment and participation in decision-making processes differs across diverse regions and localities. In contrast to women's severe underrepresentation in the Russian highest legislature, Sovet Federatsii, there are strong grassroots movements towards growing female empowerment in the Arctic at both the regional level of government legislature and the local level of self-government institutions-in particular, in indigenous communities.

Indigenous women in the Arctic have come a long way over the last 80 years, from occupying traditional gender roles within families to consistent and confident political leadership in self-government bodies throughout rural Northern communities. This study is the first attempt to highlight the NAO as an important case study for female leadership in the regional and municipal (local) levels with a special focus on rural indigenous communities where female deputies tend to form a vast or an overwhelming majority in self-government bodies.

As a result of Soviet policies on women's empowerment that transformed traditional social institutions in the Arctic, three major and interrelated vectors have emerged in the NAO's predominantly indigenous municipalities: (1) a growing gender gap in occupational aspirations, with young indigenous men bound by traditionalist male expectations, while young women have gained access to a wider range of career choices; (2) the rise of women's political and social capital that contributes to a "reverse gender disparity" in local self-governance bodies where men are grossly underrepresented in leadership roles; and (3) a gradual development of grassroots movements by emerging female indigenous political and social elite capable of playing a greater role in decolonization processes and reinforcing an indigenous "fate-control" in the Arctic.

The NAO case shows that Soviet practices might be taken into consideration for achieving effective SDG5 implementation, as the policies that provided educational opportunities to both women and men and established a legal framework for gender equality undoubtedly contributed to the growing leadership of women in the Arctic. However, introducing these institutional changes without profound shifts in socio-cultural norms, values, and everyday practices can undermine efforts toward long-term sustainable development, potentially giving rise to such phenomena as "reverse gender disparity" and male social and political marginalization. In order to realize a highly complex task of gender equality 
by 2030, as enshrined in SDG5, a holistic approach to women's empowerment requires taking into account socio-cultural and historical contexts, as well as regional and territorial disparities.

Author Contributions: Conceptualization, M.S.R. and V.L.M.; Data curation, M.S.R.; Methodology, M.S.R. and V.L.M.; Project administration, M.S.R.; Writing—original draft, M.S.R. and V.L.M.; Writing—review \& editing, M.S.R. All authors have read and agreed to the published version of the manuscript.

Funding: This paper is partly based on research on Indigenous urbanization in the Russian Arctic undertaken as part of the Program for International Research and Education (PIRE) project "Promoting Urban Sustainability in the Arctic" (NSF Award \#1545913).

Acknowledgments: The authors are grateful to Marlene Laruelle (GWU) and Robert Orttung (GWU), for their support for the field research in the NAO in 2017-2018, as well as for the financial support from the PIRE's project "Promoting Urban Sustainability in the Arctic" (NSF Award \#1545913). Our deep appreciation goes to the Russian Association of Indigenous Peoples of the North (RAIPON) and the Nenets Indigenous Association 'Yasavey' for their guidance on Indigenous matters. We also want to express our gratitude to all survey participants, in particular the students at Pyrerka boarding school in Naryan-Mar, who shared their career plans. Finally, our deep appreciation goes to Kathryn Urban for pedagogic editing, and the anonymous reviewers for their highly valuable comments and great ideas for future research directions.

Conflicts of Interest: The authors declare no conflicts of interest.

\section{References and Notes}

Alexander, Amy C., Catherine Bolzendahl, and Farida Jalalzai, eds. 2018. Measuring Women's Political Empowerment across the Globe: Strategies, Challenges and Future Research. Cham: Palgrave Macmillan.

Ayvazova, Svetlana. 1998. Russkie zhenshchiny v labirinte ravnopraviia (ocherki politicheskoi teorii i istorii). Moscow: RIK Rusanova.

Ayvazova, Svetlana. 2014. Transformatsiia gendernogo poryadka v stranakh SNG: institutsional'nyye faktory i effekty massovoi politiki. Zhenshchina $v$ rossiiskon obshchestve 4: 11-23.

Ayvazova, Svetlana. 2016. Gendernyi rakurs massovoi politiki. Zhenshchina v rossiiskom obshchestve 1: 24-34.

Ayvazova, Svetlana. 2017. Gendernyi diskurs v pole konservativnoi politiki. Zhenshchina v rossiiskom obshchestve 4: 3-13.

Bennett, Lynn. 2002. Using Empowerment and Social Inclusion for Pro-poor Growth: A Theory of Social Change. Working Draft of Background Paper for the Social Development Strategy Paper. Washington, DC: World Bank.

Blomberg, Eva, Yulia Gradskova, Ylva Waldemarson, and Alina Žvinklienè. 2017. Gender Equality on a Grand Tour: Politics and Institutions-The Nordic Council, Sweden, Lithuania and Russi. Leiden: BRILL.

Bodenhorn, Barbara. 1990. "I'm not the great hunter, my wife is": Inupiat and anthropological models of gender. Etudes/Inuit Studies 14: 55-74.

Carson, Dean, Rasmus Ole Rasmussen, Prescott Ensign, Lee Huskey, and Andrew Taylor, eds. 2011. Demography at the Edge: Remote Human Populations in Developed Nations. Burlington: Ashgate.

Chandler, Andrea. 2013. Democracy, Gender and Social Policy in Russia. Basingstoke: Palgrave McMillan.

Dahl, Jens. 2010. Identity, Urbanization and Political Demography in Greenland. Acta Borealia 27: 125-40. [CrossRef]

Decree of the Government of the Russian Federation of March 14, 2018 No. 420-R "National Strategy and Action Plan for Women for the Period 2017-2022."

Dorzheyeva, Viktoria. 2013. Izmeneniia v polozhenii zhenshchin korennykh malochislennykh narodov Severo-Vostoka Rossii (nachalo XX-konets XX v.). Ph.D. dissertation, Buryat State University, Ulan-Ude, Buryatia, Russia.

Eikjok, Jorunn. 2007. Gender, essentialism and feminism in Samiland. In Making Space for Indigenous Feminism. Edited by Joyce Green. London: Zed Books, pp. 108-23.

Einhorn, Barbara. 2006. Citizenship in Enlarged Europe: From Dream to Awakening. Basingstoke: Palgrave McMillan. Engel, Barbara Alpern, and Anastasia Posadskaya-Vanderbeck. 1998. A Revolution of Their Own. Boulder: Westview Press.

Fogel-Chance, Nanacy. 1993. Living in Both Worlds: "Modernity" and "Tradition" among North Slope Iñupiaq Women in Anchorage. Arctic Anthropology 30: 94-108. 
Global Gender Gap Report. 2018. Cologny/Geneva: World Economic Forum. Available online: http://www3. weforum.org/docs/WEF_GGGR_2018.pdf (accessed on 27 October 2019).

Hamilton, Lawrence. 2010. Footprints: Demographic Effects of Out-Migration. In Migration in the Circumpolar North: Issues and Contexts. Edited by Lee Huskey and Chris Southcott. Edmonton: Canadian Circumpolar Institute, pp. 1-14.

Hamilton, Lawrence, and Rasmos Ole Rasmussen. 2010. Population, Sex Ratios and Development in Greenland. Arctic 63: 43-52. [CrossRef]

Hamilton, Lawrence, and Carole L. Seyfrit. 1994. Female Flight? Gender Balance and Out-migration by Native Alaskan Villagers. Arctic Medical Research 53: 189-93.

Hamilton, Lawrence, Rasmus Ole Rasmussen, Nicholas E. Flanders, and Carole L. Seyfrit. 1996. Outmigration and Gender Balance in Greenland. Arctic Anthropology 33: 89-97.

Heitlinger, Alena. 1979. Women and State Socialism. Montreal: McGill-Queen's University Press.

Heleniak, Timothy. 2019. Where did all the men go? The changing sex composition of the Russian North in the post-Soviet period, 1989-2010. Polar Record, 1-14. [CrossRef]

Inglehart, Ronald, and Pippa Norris. 2003. Rising Tide Gender Equality and Culture Change Around the World. Cambridge: Cambridge University Press.

Irlbacher-Fox, Stephanie. 2015. Political participation of women in the Northwest Territories (NWT), Canada. In Gender Equality in the Arctic: Current Realities, Future Challenges; Edited by Embla Eir Oddsdóttir, Atli Már Sigurðsson and Sólrún Svandal. Reykjavik: Ministry for Foreign Affairs.

Janovicek, Nancy. 2003. “Assisting Our Own": Urban Migration, Self-Governance, and Native Women's Organizing in Thunder Bay, Ontario, 1972-1989. The American Indian Quarterly 27: 548-65. [CrossRef]

Jensen, Lois, ed. 2019. The Sustainable Development Goals Report 2019. New York: United Nations Publications, Available online: https://unstats.un.org/sdgs/report/2019/The-Sustainable-Development-Goals-Report-2019. pdf (accessed on 29 November 2019).

Khakhovskaya, Lyudmila. 2016. Gendernyi aspekt urbanizatsii korennykh narodov Magadanskoi oblasti. Zhenshchina $v$ rossiiskom obshchestve 3: 63-72.

Kiselev, Aleksandr, and Nadezhda Moldanova. 2018. Obrazy zhenshchiny v traditsionnoi kul'ture severian i sovetskom ofitsioze vtoroi poloviny 30-kh godov. Vestnik ugrovedeniia 8: 568-84.

Kochergina, Ekaterina. 2017. Uchastie zhenshchin v politike. Moscow: Levada-Center, Available online: https: //www.levada.ru/2017/10/16/uchastie-zhenshhin-v-politike-2/ (accessed on 14 August 2019).

Kochkina, Ekaterina. 2003. Predstavitel'stvo zhenshchin v strukturakh vlasti Rossii, 1917-2002 gg. In Gendernaia Rekonstruktsiia Politicheskikh System. Edited by Natalia Stepanova, Mikhail Kirichenko and Elena Kochkina. St. Petersburg: Aleteiia.

Kulmala, Meri. 2010. Women rule this country: Women's community organizing and care in rural Karelia. Anthropology of East Europe Review 28: 164-85.

Kulmala, Meri. 2014. Karelian women's network: A (feminist) women's movement? In Women and Transformation in Russia. Edited by Aino Saarinen, Kirsti Ekonen and Valentina Uspenskaia. London: Routledge, pp. $163-88$.

Lapidus, Gail Warshofsky. 1978. Women in Soviet Society Equality, Development, and Social Change. Berkeley: University of California Press.

Larsen, Joan Nymand, and Gail Fondahl, eds. 2014. Arctic Human Development Report: Regional Processes and Global Linkages. Copenhagen: Norden.

Larsen, Joan Nymand, Peter P. Schweitzer, and Andrey Petrov. 2015. Arctic Social Indicators. ASI II: Implementation. Copenhagen: Nordic Council of Ministers.

Lyarskaya, Elena. 2004. Northern residential schools in contemporary Yamal Nenets culture. Sibirica 4: 74-87. [CrossRef]

Lyarskaya, Elena. 2006. «U nikh zhe vse ne kak u liudei ... »: Nekotorye stereotipnye predstavleniia pedagogov Iamalo-Nenetskogo okruga o tundrovikakh. Antropologicheskii forum 5: 242-58.

Lyarskaya, Elena. 2010. Zhenshchiny i tundra. Gendernyi sdvig na Yamale? Antropologicheskii forum 13: 3-38.

Nabok, Igor, and Stella Serpivo. 2017. Transformatsiia zhenskogo prostranstva traditsionnoi kul'tury nentsev k nachalu 20 v. Vestnik arkheologii, antropologii i etnografii 1: 110-17. [CrossRef]

Narayan, Deepa, ed. 2002. Empowerment and Poverty Reduction: A Sourcebook. Washington, DC: World Bank. 
Neftegaz.RU. 2018. “Budet neprosto." Vlasti Nenetskogo avtonomnogo okruga khotiat snizit' zavisimost' regional'nogo biudzheta ot neftianykh tsen. Neftegaz.RU. July 25. Available online: https://neftegaz.ru/news/finance/199705-budetneprosto-vlasti-nenetskogo-avtonomnogo-okruga-khotyat-snizit-zavisimost-regionalnogo-byudzheta/ (accessed on 17 November 2019).

Norris, Pippa. 2004. Electoral Engineering. Cambridge: Cambridge University Press.

Norris, Mary Jane, Stewart Clatworthy, and Evelyn Peters. 2013. The Urbanization of Aboriginal Populations in Canada: A Half Century in Review. In Indigenous in the City: Contemporary Identities and Cultural Innovation. Edited by Evelyn Peters and Chris Andersen. Vancouver: UBC Press Canada, pp. 29-45.

Oddsdóttir, Embla Eir, Atli Már Sigurðsson, and Sólrún Svandal, eds. 2015. Gender Equality in the Arctic: Current Realities, Future Challenges; Reykjavik: Ministry for Foreign Affairs.

Perevalova, Elena. 2015. Interv'iu s olenevodami Yamala o padezhe oleney i perspektivakh nenetskogo olenevodstva. Uralskiy istoricheskiy vestnik 2: 39-49.

PIRE Indicators. 2019. Program for International Research and Education Project: Promoting Urban Sustainability in the Arctic. Available online: https://blogs.gwu.edu/arcticpire/ (accessed on 22 November 2019).

Povoroznyuk, Olga, Joachim Otto Habeck, and Virginie Vaté. 2010. Povoroznyuk, Olga, Joachim Otto Habeck, and Virginie Vaté. 2010. On the definition, theory, and practice of gender shift in the North of Russia: Introduction. Anthropology of East Europe Review 28: 1-37.

Racioppi, Linda, and Katherine O'Sullivan See. 2009. Gender Politics in Post-Communist Eurasia. East Lansing: Michigan State University Press.

Rasmussen, Rasmus Ole. 2007. Polar Women Go South. Journal of Nordregio 7: 20-22.

Rasmussen, Rasmus Ole. 2015. Gender Perspectives on Path Dependency (Paper presentation). In Gender Equality in the Arctic: Current Realities, Future Challenges; Edited by Embla Eir Oddsdóttir, Atli M\&\#xE1;r Sigurðsson and Sólrún Svandal. Reykjavik: Ministry for Foreign Affairs.

Rozanova, Marya. 2019. Indigenous Urbanization in Russia's Arctic: The Case of Nenets Autonomous Region. Sibirica 18: 54-91. [CrossRef]

Saarinen, Aino, Kirsti Ekonen, and Valentina Uspenskaia, eds. 2014. Women and Transformation in Russia. London: Routledge.

Sachs, Jeffrey, Guido Schmidt-Traub, Christian Kroll, Guillaume Lafortune, and Grayson Fuller. 2019. Sustainable Development Report 2019. New York: Bertelsmann Stiftung and Sustainable Development Solutions Network (SDSN).

Segovia-Pérez, Mónica, Pilar Laguna-Sánchez, and Concepción de la Fuente-Cabrero. 2019. Education for Sustainable Leadership: Fostering Women's Empowerment at the University Level. Sustainability 11: 5555. [CrossRef]

Serpivo, Stella. 2014. K voprosu o gendernom prostranstve v traditsionnoi kul'ture nentsev. In Sibirskiy sbornik-4: Grani sotsial'nogo: Antropologicheskiye perspektivy issledovaniya sotsial'nykh otnosheniy i kul'tury. Edited by Vladimir Davydov and Dmitriy Arzyutov. St. Petersburg: MAE RAN, pp. 442-48.

Slezkine, Yuri. 1994. Arctic Mirrors: Russia and the Small Peoples of the North. Ithaca: Cornell University Press.

Sobranie deputatov Official Website. 2019. Available online: www.sdnao.ru (accessed on 12 December 2019).

Sokolovskiy, Sergey. 2008. Korennyye narody: mezhdu integratsiei i sokhraneniem kul'tur. In Etnicheskiye kategorii i statistika. Debaty v Rossii i vo Frantsii. Edited by Elena Filippova. Moscow: FGNU "Rosinformagrotekh".

Sovet Federatsii Official Website. 2019. Available online: council.gov.ru (accessed on 29 December 2019).

Ssorin-Chaikov, Nikolai V. 2003. The Social Life of the State in Subarctic Siberia. Stanford: Stanford University Press. State Duma Official Website. 2019. Available online: duma.gov.ru (accessed on 29 December 2019).

Sumarokov, Yury, Tormod Brenn, Alexander V. Kudryavtsev, and Odd Nilssen. 2014. Suicides in the Indigenous and non-Indigenous populations in the Nenets Autonomous Okrug, Northwestern Russia, and associated socio-demographic characteristics. International Journal of Circumpolar Health 73: 24308. [CrossRef]

Sundström, Aksel, and Lena Wängnerud. 2018. Women's Empowerment at the Local Level. In Measuring Women's Political Empowerment across the Globe: Strategies, Challenges and Future Research. Edited by Amy C. Alexander, Catherine Bolzendahl and Farida Jalalzai. Cham: Palgrave Macmillan, pp. 117-37.

Tarmakhanov, Efrem, and Elizaveta Badmatsyrenova. 2010. Institutsional'nye aspekty gosudarstvennoi politiki po vovlecheniiu zhenshchin $\mathrm{v}$ obshchestvenno-politicheskuiu deiatel'nost' v usloviiakh natsional'nogo regiona (na primere Buryat-Mongol'skoi ASSR). Gumanitarnyy vektor 3: 54-58. 
Taylor, Andrew. 2011. Current evidence of 'female flight' from remote Northern Territory Aboriginal communities-Demographic and policy implications. Migration Letters 8: 77-89. [CrossRef]

The 1918 Constitution of the Russian Soviet Federative Socialist Republic. 1918. Available online: http://constitution. garant.ru/science-work/modern/3988990/ (accessed on 2 September 2019).

The 1936 Constitution of the Soviet Union. 1936. Available online: http://www.departments.bucknell.edu/russian/ const/1936toc.html (accessed on 2 September 2019).

The Law of the Nenets Autonomous District. 2008. “On State Support of Traditional Types of Management and Industries of the Indigenous Minorities of the North in the Nenets Autonomous Region" of January 28, 2008, No. 1-OZ; Federal Law of the Russian Federation “On Guarantees of the Rights of Indigenous Minorities of the Russian Federation" of April 30, 1999, No. 82-FZ; The Federal Law of the Russian Federation "On the Territories of Traditional Nature Use of the Indigenous Minorities of the North, Siberia and the Far East of the Russian Federation" of May 7, 2001, No. 49-FZ; Federal Law of the Russian Federation "On the General Principles of the Organization of Communities of Indigenous Minorities of the North, Siberia and the Far East of the Russian Federation" of July 20, 2000, No. 104-FZ; Federal Law of the Russian Federation "On Fisheries and the Conservation of Aquatic Biological Resources" of December 20, 2004, No. 166-FZ; Federal Law of the Russian Federation "On Hunting and on the Conservation of Hunting Resources and on Amendments to Certain Legislative Acts of the Russian Federation" of July 24, 2009, No. 209-FZ.

The Russian Census of 2002. 2002. Federal State Statistics Service of Russia. Available online: http://www. perepis2002.ru/index.html?id=11 (accessed on 19 September 2019).

The Russian Census of 2010. 2010. Federal State Statistics Service of Russia. Available online: https://gks.ru/free_ doc/new_site/perepis2010/croc/perepis_itogi1612.htm (accessed on 19 September 2019).

The Russian Orthodox Church. 2006. Orthodox Declaration on Human Rights and Dignity. Paper presented at The Tenth World Russian People's Council, Moscow, Russia, April 6; Available online: http://www.pravoslavieto. com/docs/human_rights/declaration_ru_en.htm (accessed on 9 October 2019).

Tuisku, Tuula. 2001. The displacement of Nenets women from reindeer herding and the tundra in the Nenets autonomous okrug, Northwestern Russia. Acta Borealia 18: 41-60. [CrossRef]

UN General Assembly. 2015. Transforming Our World: The 2030 Agenda for Sustainable Development; A/RES/70/1. New York: UN General Assembly. Available online: https://www.refworld.org/docid/57b6e3e44.html (accessed on 22 November 2019).

UN Women. 2016. Progress of the World's Women 2015-2016: Transforming Economies, Realizing Rights; New York: United Nations Entity for Gender Equality and the Empowerment of Women. Available online: http: //progress.unwomen.org/en/2015/pdf/UNW_progressreport.pdf (accessed on 25 November 2019).

Upadhyay, Ushma D., Jessica D. Gipson, Mellissa Withers, Shayna Lewis, Erica J. Ciaraldi, Ashley Fraser, Megan J. Huchko, and Ndola Prata. 2014. Women's empowerment and fertility: A review of the literature. Social Science \& Medicine 115: 111-20.

Ventsel, Aimar. 2018. Blurring masculinities in the Republic of Sakha, Russia. Polar Geography 41: $198-216$. [CrossRef]

Vinokurova, Liliya. 2017. Zhenshchiny korennykh narodov severa: Kochevnitsy Yakutii v meniaiushchemsia mire. In Cila slabykh: Gendernye aspekty vzaimopomoshchi i liderstva v proshlom $i$ nastoyashchem. Edited by Natalya Pushkareva and Tatiana Troshina. Moscow: RAIZHI \& IEA RAN, pp. 15-18.

Vinokurova, Liliya, Alena Popova, Sardana Boyakova, and Elvira Myarikyanova. 2004. Zhenshchina Severa: Poisk novoi sotsial'noi identichnosti. Novosibirsk: Novosibirskoe otdelenie izdatel'stva "Nauka".

Vladimirova, Vladislava. 2018. Security strategies of Indigenous women in Nenets Autonomous Region, Russia. Polar Geography 411: 164-81. [CrossRef]

Vladimirova, Vladislava, and Otto J. Habeck. 2018. Introduction: Feminist Approaches and the Study of Gender in Arctic Social Sciences. Polar Geography 41: 145-63. [CrossRef]

(C) 2020 by the authors. Licensee MDPI, Basel, Switzerland. This article is an open access article distributed under the terms and conditions of the Creative Commons Attribution (CC BY) license (http://creativecommons.org/licenses/by/4.0/). 